\title{
Evaluation of borax solid wastes in production of frits suitable for fast single-fired wall tile opaque glass-ceramic glazes ${ }^{\dagger}$
}

\author{
K PEKKAN ${ }^{1,2, *}$ and B KARASU ${ }^{1}$ \\ ${ }^{1}$ Department of Materials Science and Engineering, Anadolu University, 26480 Eskisehir, Turkiye \\ ${ }^{2}$ Kaleseramik Canakkale Kalebodur Seramik Sanayi A.S., 17430 Can, Canakkale, Turkiye
}

MS received 3 December 2008; revised 14 April 2009

\begin{abstract}
Zircon (zirconium silicate, $\mathrm{ZrSiO}_{4}$ ) is the main opacifier of glossy, opaque, white-coloured, fritbased wall tile glazes. However, zirconia containing frits employed in the preparation of these glazes raise the production cost limiting zircon usage as a raw material at an industrial scale. Therefore, there have been several searches on seeking for alternative frit compositions with lower or without zirconia content. Consequently, positive outcomes were recently reported. With the present study, $1.5-5 \%$ of borax concentrator waste replaced certain level of acid boric for $\mathrm{B}_{2} \mathrm{O}_{3}$ content in a low zircon containing frit recipe. It is confirmed that waste contribution did not distort the surface properties of the fast single-fired wall tile opaque glazes. Zircon was found to be the main crystal phase of the glazes in laboratory trials. Industrial applications revealed that shorter firing cycles lead to zircon and petedunnite $\left(\mathrm{CaZnSi}_{2} \mathrm{O}_{6}\right)$ formation in the $\mathrm{CW}-4$ glaze.
\end{abstract}

Keywords. Borax solid wastes; evaluation; wall tiles; glass-ceramic glazes; fast single-firing.

\section{Introduction}

Frits are the indispensable constituents of most industrial glazes which mature at the temperatures below $1150^{\circ} \mathrm{C}$ (Taylor and Bull 1986). The opacity of the traditional wall tile opaque glazes usually originates through hardening of glass matrix by adding high amounts of zirconia containing frits into their batches (Yekta et al 2006). Nowadays, researchers point out that certain types of glass-ceramic layers can be alternatively employed as tile coatings lowering the use of zirconia containing expensive opaque frits. One of the best methods to obtain an opaque glaze surface is to induce a crystal phase in the coating, whose refractive index significantly differs from that of the glassy matrix. The opacity of such a coating is determined by the diffusion, refraction and reflection of light through the layer which contains emerging crystals, and the degree of opacity mainly depends on the size and quantity of crystals (Taylor and Bull 1986; Yekta et al 2006).

The development of glazes not possessing expensive or toxic components is of special interest (Moreva and Levitskii 2006). When compared to raw glazes fritted ones decrease melting temperatures and consequently, the

\footnotetext{
*Author for correspondence (karavelikeriman@yahoo.com)

${ }^{\dagger}$ Some part of this study was orally presented in REWAS 2008 Congress in Cancun Mexico, October 2008 and the copyright for such parts belongs to TMS.
}

glaze maturation time is narrowed, smooth and bright surfaces can easily be formed. The bright and transparent glaze appearances can be changed with the opacification supplied by one or more crystal phases and zirconium compounds are the most effective ones in that term. In recent years, high prices of some raw materials led to searches directed on seeking new alternatives to reduce the production cost. Previously done studies (Pekkan et al $2007,2008 \mathrm{a}-\mathrm{d}, 2009 \mathrm{a}$, b) pointed out that the amount of zircon could be decreased and even completely eliminated in frit recipes.

Some ceramics have been manufactured by using suitable wastes as a raw material to reduce the production cost. In addition, there has recently been much interest in providing a market for a product, in which wastes were evaluated, thereby reducing the volume of waste that must ultimately be disposed off (Chiang et al 1994). For instance, borax solid wastes have been re-cycled in the manufacture of glass-ceramics suitable for glaze applications. Acid boric is the main $\mathrm{B}_{2} \mathrm{O}_{3}$ resource of frit recipes. In the glazes, $\mathrm{B}_{2} \mathrm{O}_{3}$ reduces the softening and melting temperatures, lowers surface tension and improves their mechanical and thermal properties. Moreover, it influences the aesthetic characteristics of the coating. Therefore, supplying $\mathrm{B}_{2} \mathrm{O}_{3}$ through a suitable waste is of economical, technical and environmental importance. There have been some researches conducted on the evaluation of borax solid wastes in single fast-fired floor and porcelain tile glazes, in which certain oxides were brought up to an optimum level through the wastes (Karasu et al 2006a-d; 
Table 1. Compositional details of studied frits (in moles).

\begin{tabular}{lccccccc}
\hline Frits & $\mathrm{Al}_{2} \mathrm{O}_{3} / \mathrm{SiO}_{2}$ & $\mathrm{Al}_{2} \mathrm{O}_{3} / * \sum \mathrm{R}_{2} \mathrm{O}$ & $\mathrm{Al}_{2} \mathrm{O}_{3} / * * \sum \mathrm{RO}$ & $\mathrm{Al}_{2} \mathrm{O}_{3} / \mathrm{B}_{2} \mathrm{O}_{3}$ & $\mathrm{CaO} / \mathrm{MgO}$ & $\mathrm{ZrO}_{2}$ & $\mathrm{ZnO}$ \\
\hline $\mathrm{HZG}$ & 0.06 & 1.73 & $0 \cdot 14$ & 3.25 & 2.58 & $x$ & $y$ \\
LZG & 0.04 & 0.38 & 0.08 & 0.38 & $2 \cdot 19$ & $x-0.01$ & $y-0.24$ \\
CW1-4 & 0.04 & 0.38 & 0.08 & 0.38 & 2.19 & $x-0.01$ & $y-0.24$ \\
\hline
\end{tabular}

$* \mathrm{Na}_{2} \mathrm{O}+\mathrm{K}_{2} \mathrm{O} ; * * \mathrm{CaO}+\mathrm{MgO}+\mathrm{ZnO}$

Table 2. Composition of the base LZG frit.

\begin{tabular}{lc}
\hline Components & Content (mol \%) \\
\hline $\mathrm{R}_{2} \mathrm{O}(\mathrm{R}: \mathrm{Na}, \mathrm{K})$ & $4 \cdot 67$ \\
$\mathrm{RO}(\mathrm{R}: \mathrm{Ca}, \mathrm{Mg}, \mathrm{Sr}, \mathrm{Zn})$ & $21 \cdot 78$ \\
$\mathrm{R}_{2} \mathrm{O}_{3}\left(\mathrm{R}: \mathrm{B}, \mathrm{Al},{ }^{*} \mathrm{Fe}\right)$ & $9 \cdot 43$ \\
$\mathrm{RO}_{2}\left(\mathrm{R}: \mathrm{Si}, \mathrm{Zr},{ }^{*} \mathrm{Ti}\right)$ & $64 \cdot 12$ \\
Total & $100 \cdot 00$ \\
\hline
\end{tabular}

${ }^{*} \mathrm{Fe}_{2} \mathrm{O}_{3}$ and $\mathrm{TiO}_{2}$ come from some raw materials and their amounts are negligible.

Kaya et al 2008). In the current work, borax concentrator wastes were incorporated into the newly synthesized, low zircon and $\mathrm{ZnO}$ containing frit recipes, from which fast single-fired wall tile opaque glass-ceramic glazes were developed.

\section{Experimental}

The frits were developed in the $\mathrm{Na}_{2} \mathrm{O}-\mathrm{K}_{2} \mathrm{O}-\mathrm{MgO}-\mathrm{CaO}-$ $\mathrm{SrO}-\mathrm{ZnO}-\mathrm{Al}_{2} \mathrm{O}_{3}-\mathrm{B}_{2} \mathrm{O}_{3}-\mathrm{ZrO}_{2}-\mathrm{SiO}_{2}$ glass-ceramic system. In the previously done study $25 \%$ reduction of both zircon and zinc oxide in the frit batch (LZG) was achieved with respect to the industrially used commercial frit ( $\mathrm{HZG}$ ) containing $6-10 \% \mathrm{ZrO}_{2}$ and $6-10 \% \mathrm{ZnO}$ for glossy white opaque wall tile glaze (table 1). Request for certain boric oxide content in the $L Z G$ frit with low zirconia (4.5-7.5\%) and $\mathrm{ZnO}(4 \cdot 5-7.5 \%)$ taken as a reference for the present study (table 2) was fulfilled with Eti Maden Kirka Boron Company borax concentrator wastes $(\mathrm{CW})$, chemical composition of which is indicated in table $3.1 \cdot 5-5 \%$ of $\mathrm{CW}$ was added into the $\mathrm{LZG}$ frit and the new frit recipes were named as CW 1-4 (table 4).

The weighed and thoroughly mixed batches were melted in alumina crucibles in a laboratory type, electricallyheated furnace (Protherm PLF 160/7) at $1450^{\circ} \mathrm{C}$ for $1 \mathrm{~h}$. The melt was then quenched by pouring into cold water to obtain frits under laboratory working conditions.

The glass transition and the crystallization temperatures of the studied frits were determined with a differential thermal analyser (DTA, Netzsch STA 409 PC) on samples ground to a grain size of $<63 \mu \mathrm{m}$ with a heating rate of $10^{\circ} \mathrm{C} / \mathrm{min}$ up to $1140^{\circ} \mathrm{C}$.

In order to prepare glazes suitable amounts of frit, kaolin, carboxyl methyl cellulose (CMC), sodium tripolyphosphate (STPP) and water were mixed in a ball mill for $50 \mathrm{~min}$. The slurries were applied onto industrial pre-engobed green wall tile bodies. After drying, fast single-firing took place in a laboratory type roller furnace (Nannetti Faenza ER 30) with peak temperatures resembling those industrially employed for this type of product. Under the lights of the results obtained from laboratory firing, CW 4 frit-based glaze, which was found to be the most successful one, was selected. For the industrial trial, first, frit of CW-4 was produced under laboratory conditions and then, glaze preparation and industrial firing were conducted. The optical parameters $L^{*}[(-)$ black and white $(+)], a^{*}[(-)$ green and red $(+)]$, and $b^{*}[(-)$ blue and yellow (+)] (Henkes et al 1996) of all the fired tiles were measured using a Minolta CR-300 series chromameter. Gloss was determined with a gloss-meter (Minolta Gloss 268) with $60^{\circ}$ light incident angle on the glaze surface. XRD analyses were made by a Rigaku Rint 2000 series diffractometer with $\mathrm{CuK}_{\alpha}$ radiation at $40 \mathrm{kV}$ and $30 \mathrm{~mA}$ and, the scanning velocity of $2 \% / \mathrm{min}$. XRD patterns were taken from the fired glazed tile surfaces to identify the crystal phases formed. In order to study the effect of glaze composition on the formation, size, and distribution of the opacifying crystal phases, the samples analysed with XRD were also subjected to the investigations by scanning electron microscopes [SEM (Zeiss EVO $50 \mathrm{EP}$ and Zeiss SUPRA $50 \mathrm{VP}$ at $20 \mathrm{kV}$ )] attached to EDX.

\section{Results and discussion}

$\mathrm{ZrO}_{2}$ and $\mathrm{ZnO}$ contents were lowered in the frit recipes by only modifying the original frit chemical composition with no other nucleating agent incorporated for opacification. $\mathrm{ZrO}_{2}(x$ mole) and $\mathrm{ZnO}(y$ mole) contents in the commercially available $\mathrm{HZG}$ glaze were decreased and finally, it was found that successful frit recipes could be produced by $x-0.01$ and $y-0.24$ values (table 1 ). Decreasing $\mathrm{ZrO}_{2}$ level at a constant $\mathrm{ZnO}$ content results in pinhole problem in the HZG glaze. Pinhole can be explained by the migration of small gaseous bubbles due to dissociation of carbonates, from the interior of the glaze layer toward its surface forming small craters, which do not have time enough to be filled by viscous flow of melted glaze, accordingly, more or less perceptible pinholes remained after cooling (Levitskii and Mazura 2005). If the glaze is such a kind covering the substrate at 
Table 3. Chemical composition of the borax concentrator waste (CW) used in the study (in wt. \%).

\begin{tabular}{lcccccccccc}
\hline $\mathrm{SiO}_{2}$ & $\mathrm{Al}_{2} \mathrm{O}_{3}$ & $\mathrm{TiO}_{2}$ & $\mathrm{Fe}_{2} \mathrm{O}_{3}$ & $\mathrm{CaO}$ & $\mathrm{MgO}$ & $\mathrm{Na}_{2} \mathrm{O}$ & $\mathrm{K}_{2} \mathrm{O}$ & $\mathrm{SrO}$ & $\mathrm{B}_{2} \mathrm{O}_{3}$ & $*$ L.I. \\
\hline 19.97 & 2.44 & 0.05 & 0.50 & 11.37 & 13.75 & 7.50 & 2.34 & 1.06 & 14.30 & 26.72 \\
\hline
\end{tabular}

*L.I.: losses on ignition.

Table 4. Acid boric and CW contents of the studied frits (in wt \%).

\begin{tabular}{lcc}
\hline Frits & Acid boric & Concentrator waste (CW) \\
\hline LZG & $x$ & - \\
CW-1 & $x-2.5$ & 2.5 \\
CW-2 & $x-5$ & 5 \\
CW-3 & $x-3$ & 3 \\
CW-4 & $x-1.5$ & 1.5 \\
\hline
\end{tabular}

a quite lower temperature then, there will be insufficient time for gases to escape (Eppler and Eppler 2000). In addition to $\mathrm{ZrO}_{2}$ decrement, presence of $\mathrm{R}_{2} \mathrm{O}\left(\mathrm{Na}_{2} \mathrm{O}\right.$ and $\mathrm{K}_{2} \mathrm{O}$ ) oxides strongly influences the maturation temperature in fast single-fired glossy opaque glazes. In order to increase this temperature and get rid of pinholes, both $\mathrm{Al}_{2} \mathrm{O}_{3}$ content and $\mathrm{CaO} / \mathrm{MgO}$ ratio were increased. However, higher $\mathrm{Al}_{2} \mathrm{O}_{3}$ levels result in surface defects as a consequence of high surface tension (Taylor and Bull 1986; Sorli et al 2004; Kawamura et al 2005). The glaze should have a suitable surface tension to minimize crawling of the coating away from the edges or any holes that are present on firing. In terms of gloss, whiteness and surface quality of the opaque glazes, increasing boric oxide in the composition has a positive effect (Levitskii et al 1998; Djambazov and Damgaliev 2000). When compared to the $\mathrm{HZG}$ glaze, $\mathrm{Al}_{2} \mathrm{O}_{3} / \mathrm{B}_{2} \mathrm{O}_{3}$ ratio was declined in the $\mathrm{LZG}$ by incorporating $\mathrm{B}_{2} \mathrm{O}_{3}$ to the system. In this glaze, optimum $\mathrm{Al}_{2} \mathrm{O}_{3} / \mathrm{B}_{2} \mathrm{O}_{3}$ ratio was determined as 0.38 and the surface quality of the glaze was improved. $\mathrm{ZnO}$ content decreased as $y-0.24$ mole $(20 \%)$ without changing the $\mathrm{Al}_{2} \mathrm{O}_{3} / \mathrm{SiO}_{2}$ ratio. In that glaze $\mathrm{ZrO}_{2}$ level was diminished by $x-0.01 \mathrm{~mol}(21 \%)$ by keeping the $\mathrm{Al}_{2} \mathrm{O}_{3} / \mathrm{SiO}_{2}$ and $\mathrm{CaO} / \mathrm{MgO}$ ratios constant compared to that of the HZG glaze.

Lowering $\mathrm{ZnO}$ content in a zirconia containing opaque glaze diminishes the whiteness because $\mathrm{ZnO}$ contributes to the enhancement of colour development and increases the brightness as well as improving the glaze surface quality (Djambazov and Damgaliev 2000; Kawamura et al 2005; Levitskii and Mazura 2005). These indispensable contributions of $\mathrm{ZnO}$ in opaque glazes were fulfilled with the presence of $\mathrm{B}_{2} \mathrm{O}_{3}$ and $\mathrm{Al}_{2} \mathrm{O}_{3}$ in the current study.

The comparison of $L^{*}, a^{*}, b^{*}$ and gloss values was made with those of the standard wall tile covered by LZG-based opaque white glaze with low levels of $\mathrm{ZrO}_{2}$ and $\mathrm{ZnO}$ (table 5).
Table 5. Colour $\left(L^{*}, a^{*}, b^{*}\right)$ and gloss $\left(60^{\circ}\right)$ values of the selected glazes.

\begin{tabular}{lcrcc}
\hline Glazes & $L^{*}$ & \multicolumn{1}{c}{$a^{*}$} & $b^{*}$ & Gloss $\left(60^{\circ}\right)$ \\
\hline HZG-based & $92 \cdot 67$ & $-0 \cdot 12$ & $2 \cdot 06$ & $89 \cdot 8$ \\
LZG-based (reference) & $92 \cdot 81$ & $-0 \cdot 36$ & $2 \cdot 27$ & $88 \cdot 2$ \\
CW 1-based & $89 \cdot 10$ & $0 \cdot 42$ & $2 \cdot 55$ & $77 \cdot 1$ \\
CW 2-based & $89 \cdot 33$ & $0 \cdot 18$ & $2 \cdot 73$ & $81 \cdot 7$ \\
CW 3-based & $90 \cdot 31$ & $-0 \cdot 30$ & $2 \cdot 52$ & $70 \cdot 8$ \\
CW 4-based & $91 \cdot 17$ & $-0 \cdot 62$ & $1 \cdot 36$ & $85 \cdot 6$ \\
\hline
\end{tabular}

Borax concentrator waste can be used up to $5 \mathrm{wt} . \%$ in the frit recipes by keeping the original Seger formula of the LZG constant. Thanks to this amount of waste, there was no need for Na-feldspar use in frit recipes studied.

The LZG frit was prepared in a box type industrial melting furnace and LZG-based glaze was industrially fast single-fired. However, the newly synthesized $\mathrm{CW}$ 1-4 frit recipes were prepared in the laboratory and their firings were conducted in the laboratory type roller furnace with the parameters industrially applied at $1140^{\circ} \mathrm{C}$ for a total firing time of $55 \mathrm{~min}$. In situ applications were made for the CW-4 based glaze. Since industrial firing conditions have been changed during that time period, the reference $\mathrm{LZG}$ and $\mathrm{CW}-4$ based glazes have been fired at $1140^{\circ} \mathrm{C}$ for $37 \mathrm{~min}$. Such an important time reduction in firing cycle did not affect the glaze properties. The colour $\left(L^{*}, a^{*}, b^{*}\right)$ values of $\mathrm{CW}-4$ based glaze then became $91 \cdot 20,-0.28$ and 1.91 , respectively. The gloss value was measured as $90 \cdot 8$. These results revealed that $\mathrm{CW}-4$ glaze is stable under different firing conditions and cycles.

Figure 1 shows the DTA traces of the studied frits. Although they exhibited exothermic effects, it was determined that they have different crystallization peak intensities due to the compositional changes made. $T_{\mathrm{g}}$ values of the HZG and LZG frits were measured as 718 and $713{ }^{\circ} \mathrm{C}$, respectively. The $\mathrm{HZG}$ frit exhibited two shallow exothermic peaks at 873 and $953^{\circ} \mathrm{C}$. The former one should belong to the calcium aluminium silicate $\left(\mathrm{Ca}_{3} \mathrm{Al}_{6} \mathrm{Si}_{2} \mathrm{O}_{16}\right)$ formation while the latter one to that of zircon $\left(\mathrm{ZrSiO}_{4}\right)$ whose devitrification was reported to happen at about $900-950^{\circ} \mathrm{C}$ (Amoros et al 1994; Escardino et al 1996, 2000; Taylor 2001; Quinteiro et al 2002). The LZG one demonstrated had an intense exothermic peak at $951^{\circ} \mathrm{C}$. The glass transition temperature, $T_{\mathrm{g}}$, of $\mathrm{CW} 1$ with $2.5 \%$ waste incorporation into its starting batch and CW 3 with $3 \%$ waste are 725 and $720^{\circ} \mathrm{C}$, respectively. They have higher $T_{\mathrm{g}}$ and broad exothermic 
peaks indicating relatively low crystallization rates in them. The other studied and reference frits present a similar thermal behaviour in terms of $T_{\mathrm{g}}$ and show an exothermic peak at about $950^{\circ} \mathrm{C}$, referring to the zircon crystallization.

When $10 \cdot 3-22 \cdot 4 \%$ of total boric oxide content in the LZG frit composition was replaced by boric oxide coming from $\mathrm{CW}, L^{*}, a^{*}, b^{*}$ values of the glazes did not fluctuate significantly (table 5). The $\mathrm{CW}$ 4-based glaze has the highest whiteness value $\left(L^{*}\right)$ amongst the others derived from the LZG frit. Although all the glazes present similar whiteness, their gloss values are lower than that of the standard LZG-based one (table 5). The colour values

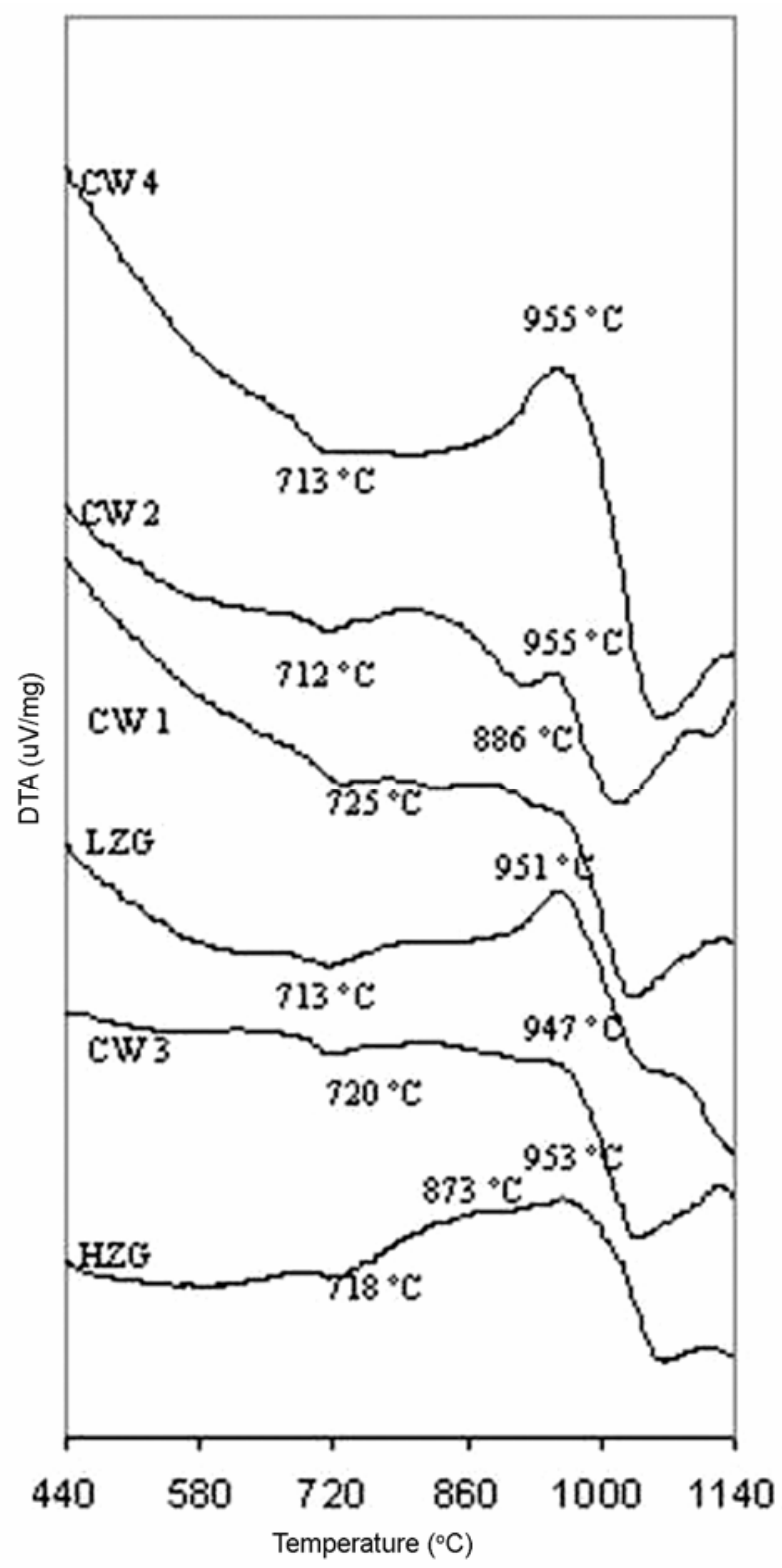

Figure 1. DTA curves of the HZG, LZG, CW1, CW2, CW3 and CW4 frits. of the glazes, in frits of which waste was evaluated, can be said alike in comparison with high level of zirconia and $\mathrm{ZnO}$ containing $\mathrm{HZG}$-based opaque glaze. According to the previous experiences it is thought that compared to the LZG-based one the decrement in gloss values of the CW 1-4-based glazes might be arising because of varying cooling conditions of the laboratory type roller furnace.

Figure 2 exhibits the XRD patterns of the phases present in the studied glazes. The HZG-based glaze experiences both calcium aluminium silicate $\left(\mathrm{Ca}_{3} \mathrm{Al}_{6} \mathrm{Si}_{2} \mathrm{O}_{16}\right)$ and zircon $\left(\mathrm{ZrSiO}_{4}\right)$ crystallizations. Apart from this, zircon is seen to be the main crystalline phase in all the other glazes fired under laboratory conditions. Although the submission of concentrator waste into frit batch did not change the type of crystal phase, it is observed that zircon peak intensities differed. The $\mathrm{CW}$ 2-based glaze has the highest level of waste incorporation $(5 \%)$ in its

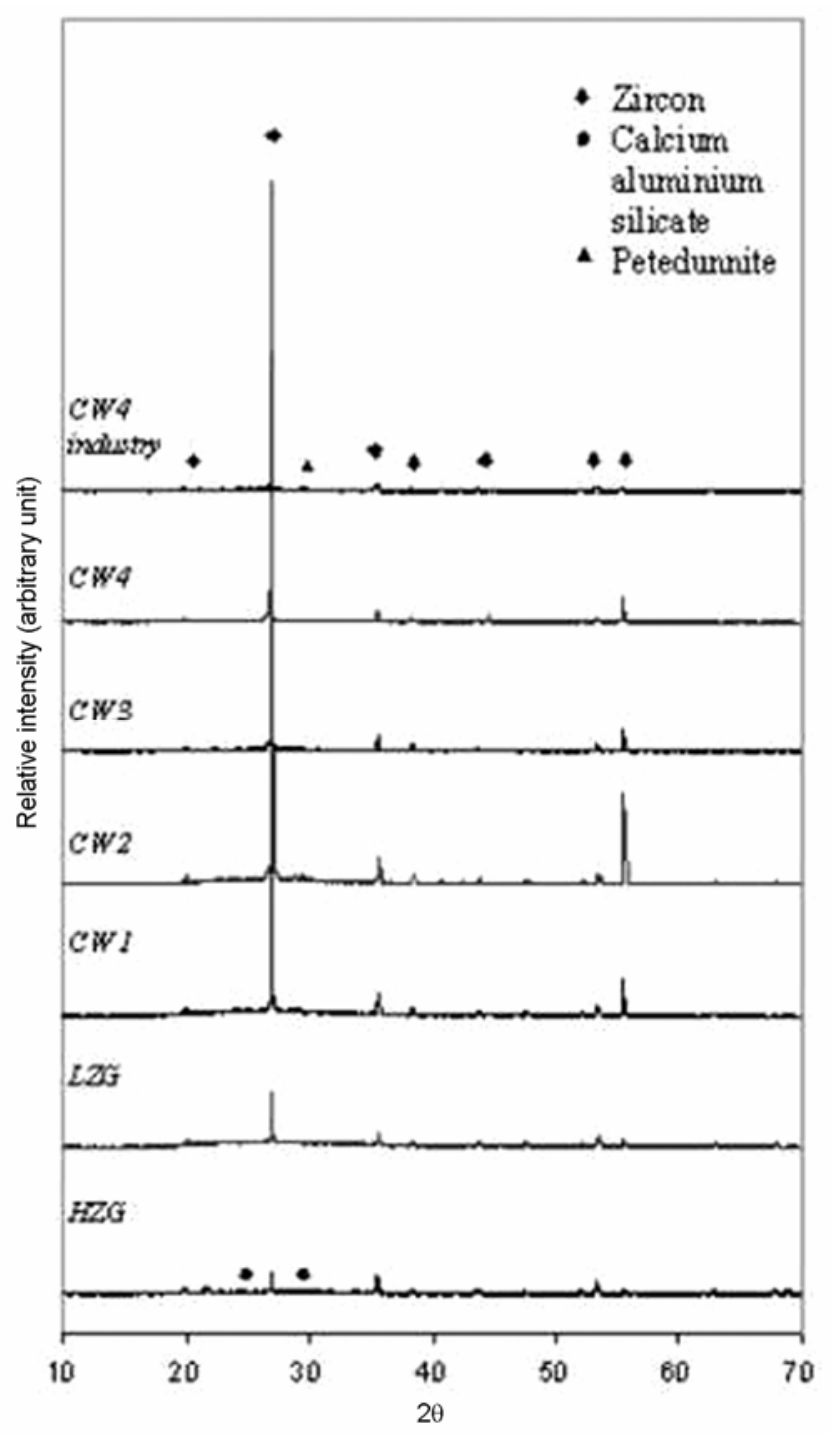

Figure 2. X-ray diffraction spectra of the HZG, LZG, CW1, CW2, CW3 and CW4 frit-based glazes. 

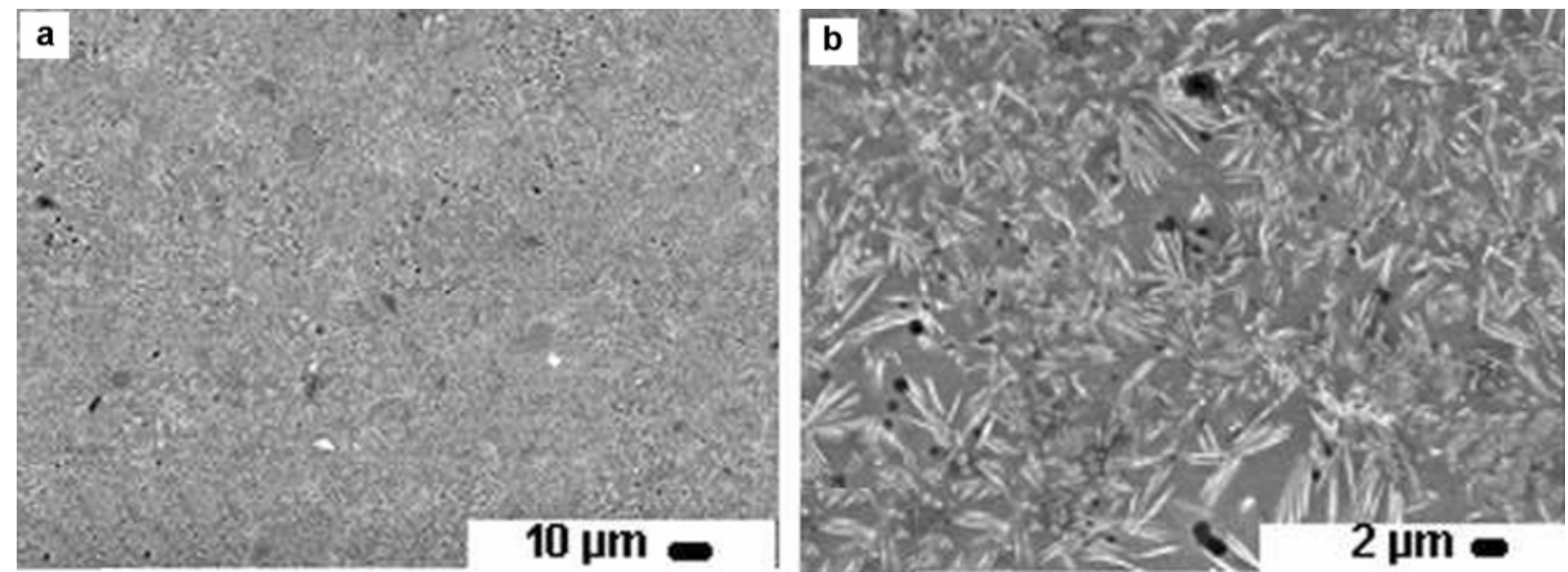

Figure 3. SEM micrographs of the HZG-based glaze showing the general $\mathbf{a}$. and detailed $\mathbf{b}$. microstructural views.
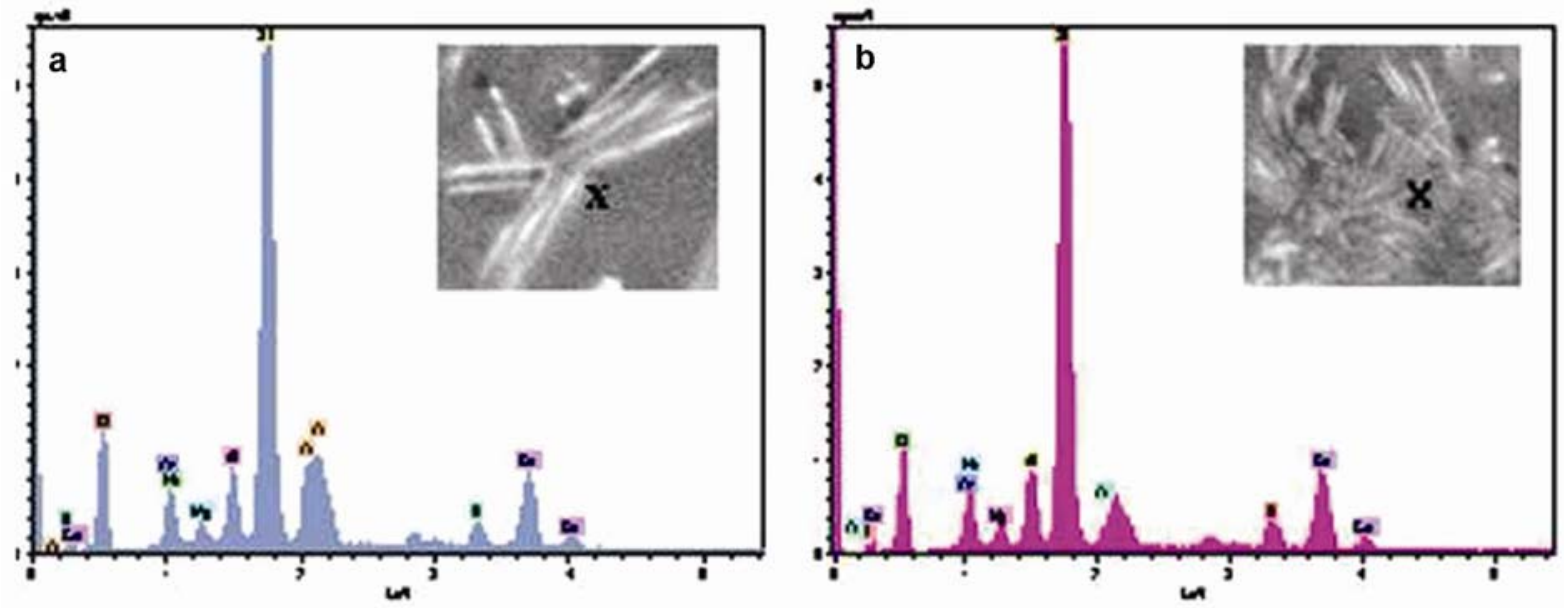

Figure 4. EDX patterns taken from the HZG-based glaze inhibiting occurrence of a. zircon and b. calcium aluminium silicate.
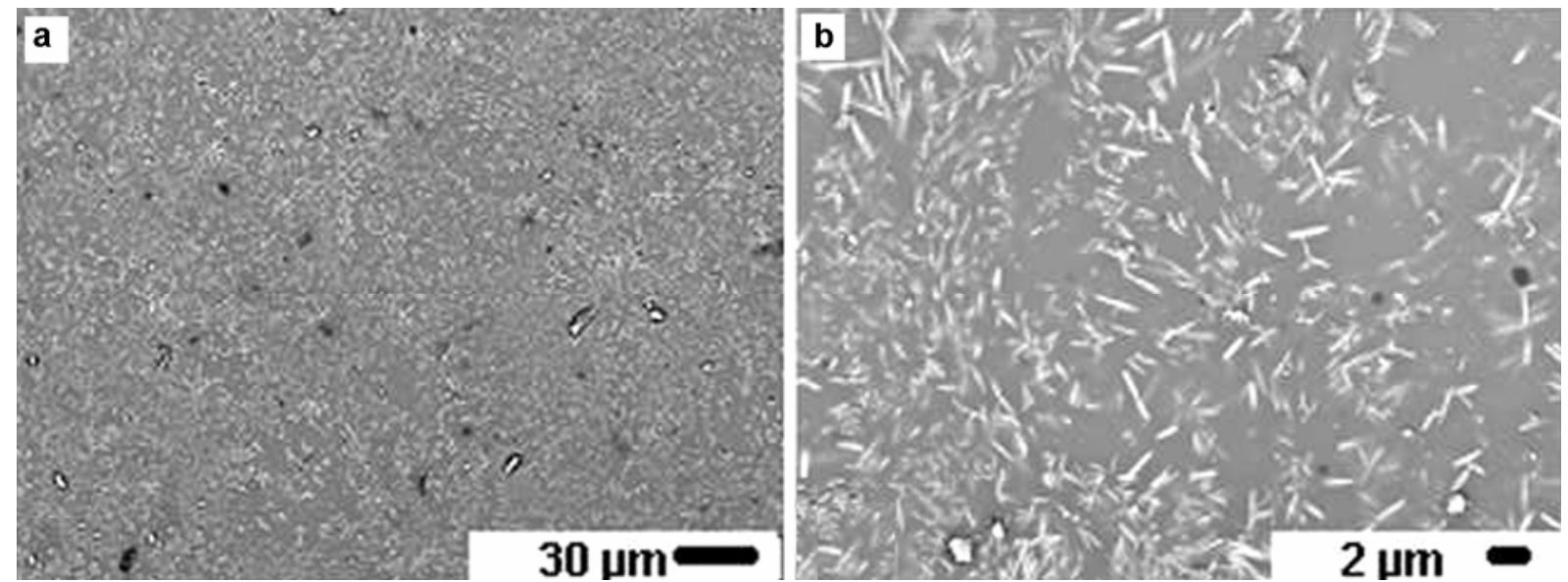

Figure 5. SEM micrographs of the LZG-based reference glaze showing a. general and b. detailed microstructural views.

frit batch and presents intense zircon peaks. The XRD results of the glazes obtained from the studied frits agreed with the DTA data confirming both calcium aluminium silicate and zircon crystallizations. It was determined that, during industrial fast single-firing of $\mathrm{CW}$ 4-based glaze, petedunnite $\left(\mathrm{CaZnSi}_{2} \mathrm{O}_{6}\right)$ also occurred besides 

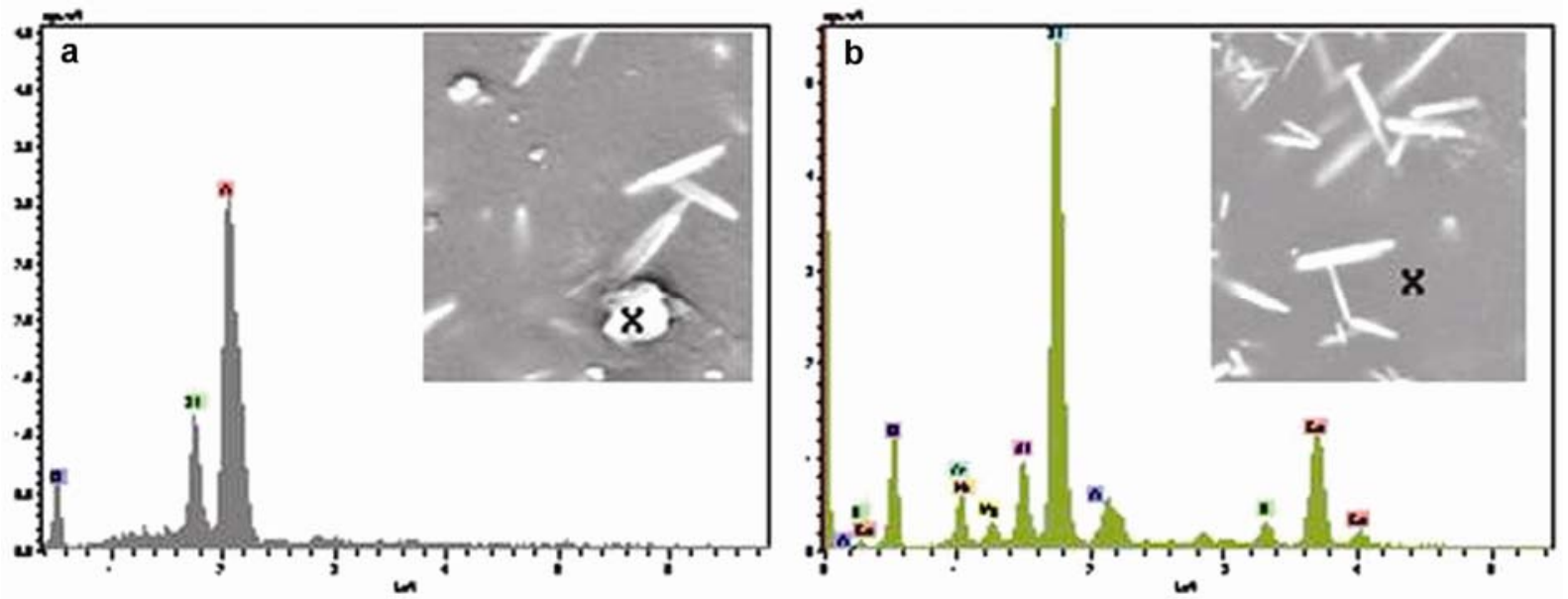

Figure 6. EDX patterns taken from the LZG-based glaze inhibiting the a. zircon occurrence and b. the elemental constitutions of the glassy phase.
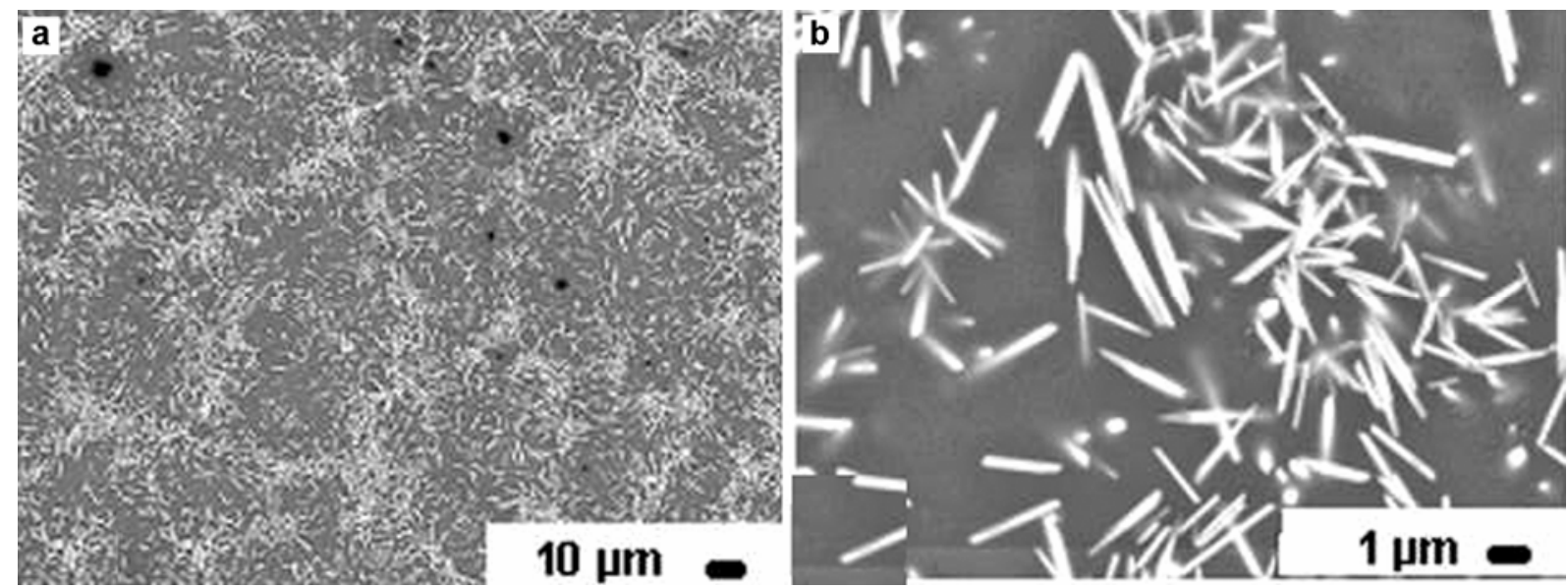

Figure 7. SEM micrographs of the CW1-based glaze showing a. general and $\mathbf{b}$. detailed microstructural views.
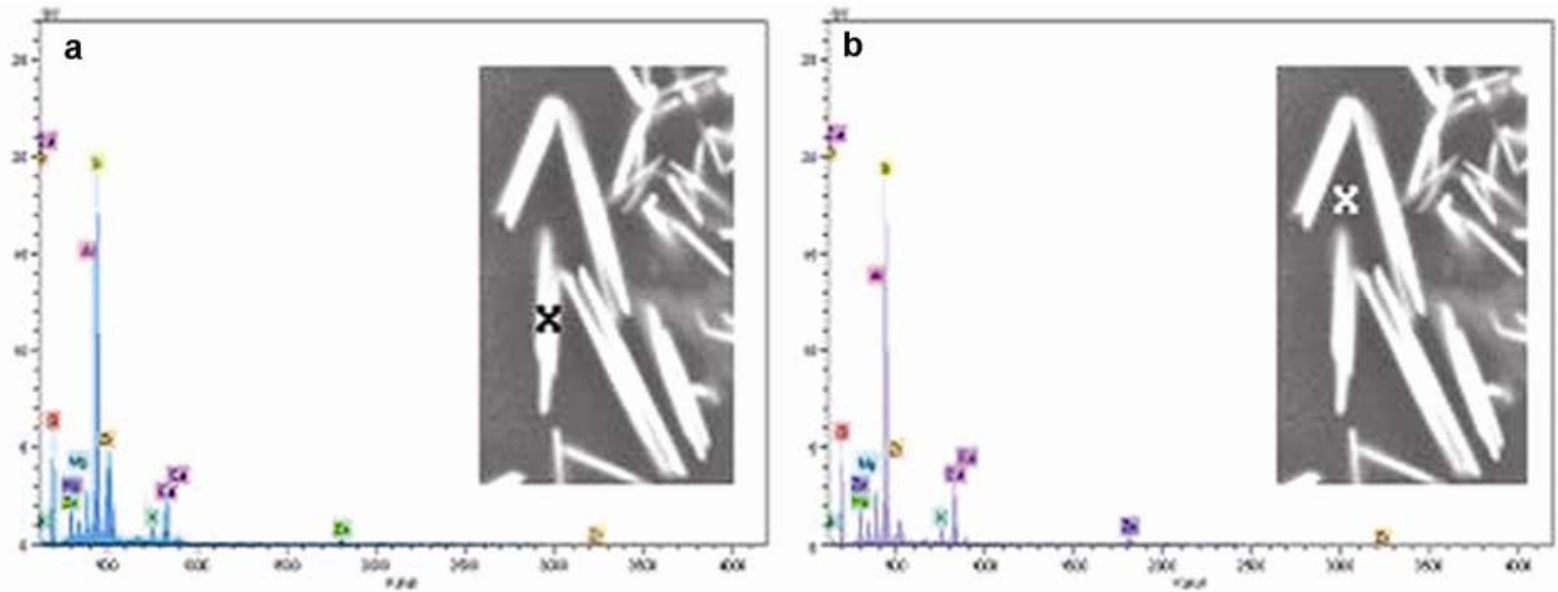

Figure 8. EDX patterns taken from the CW1-based glaze inhibiting a. zircon occurrence and b. the elemental constitutions of the glassy phase. 

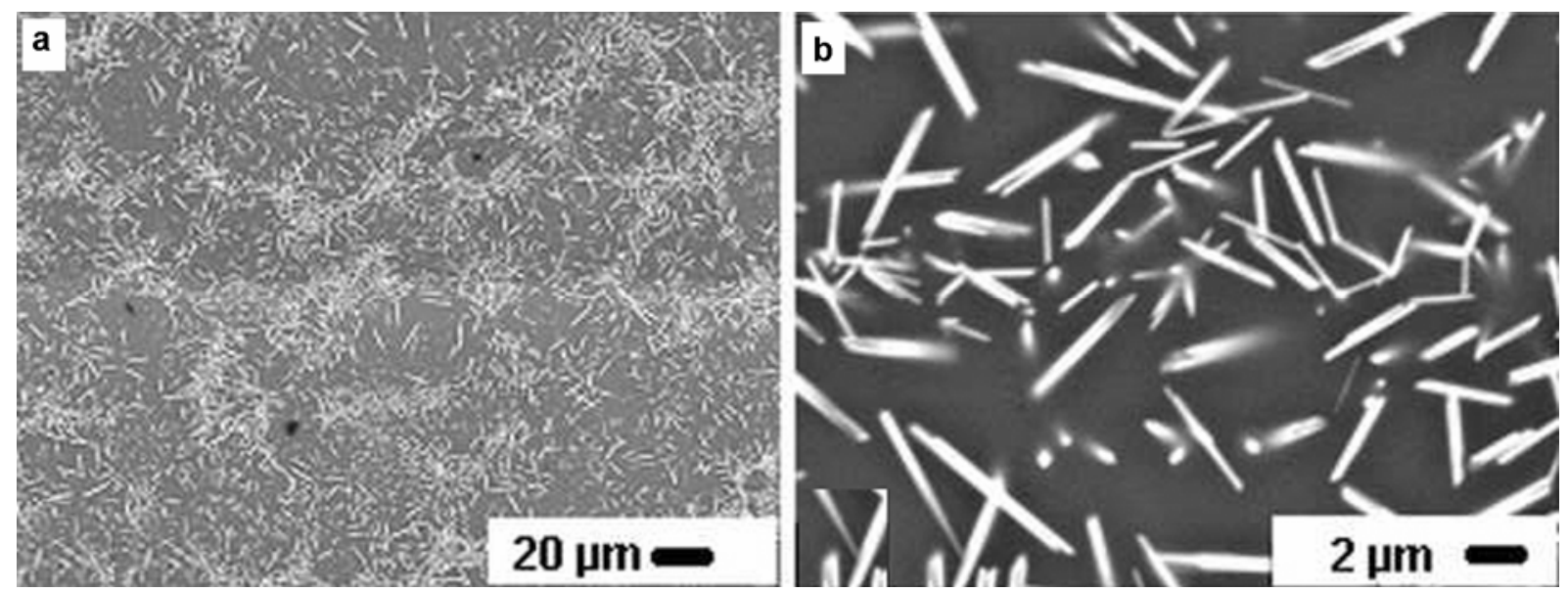

Figure 9. SEM micrographs of the CW2-based glaze presenting a. general and $\mathbf{b}$. detailed microstructural views.
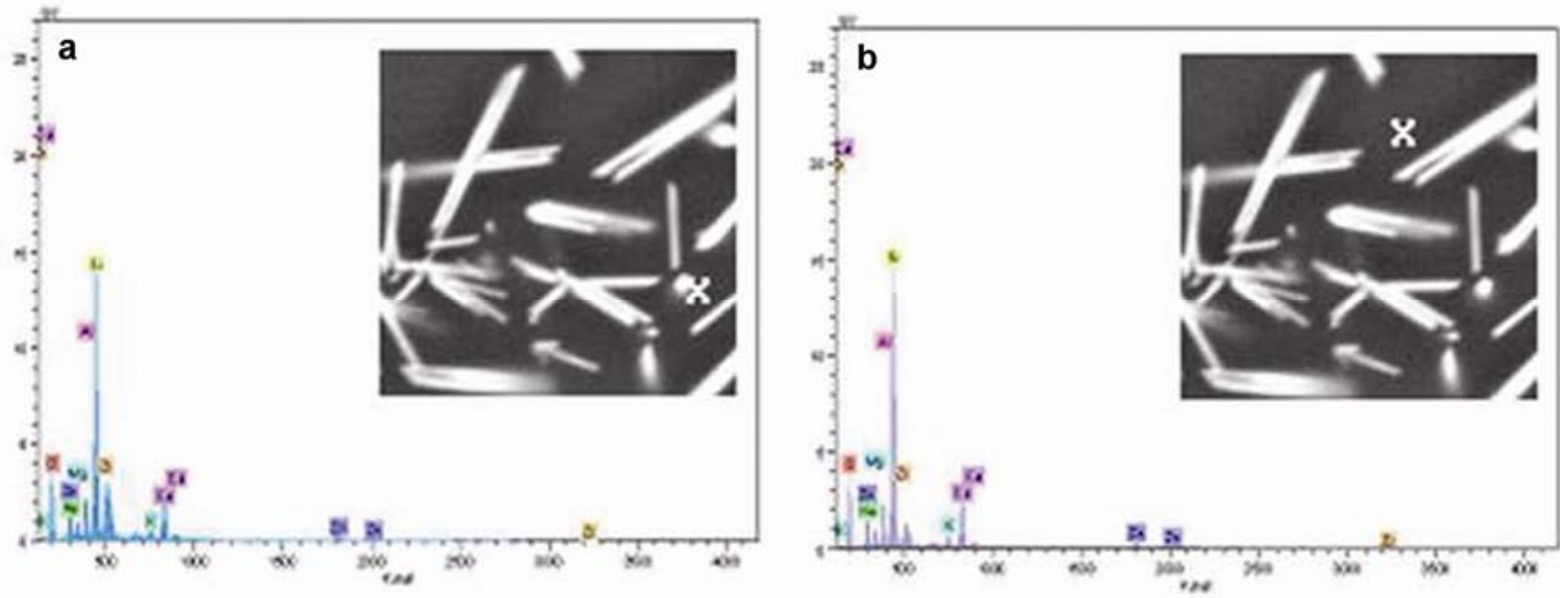

Figure 10. EDX patterns taken from the CW2-based glaze depicting a. zircon occurrence and b. elemental constitutions of the glassy phase.
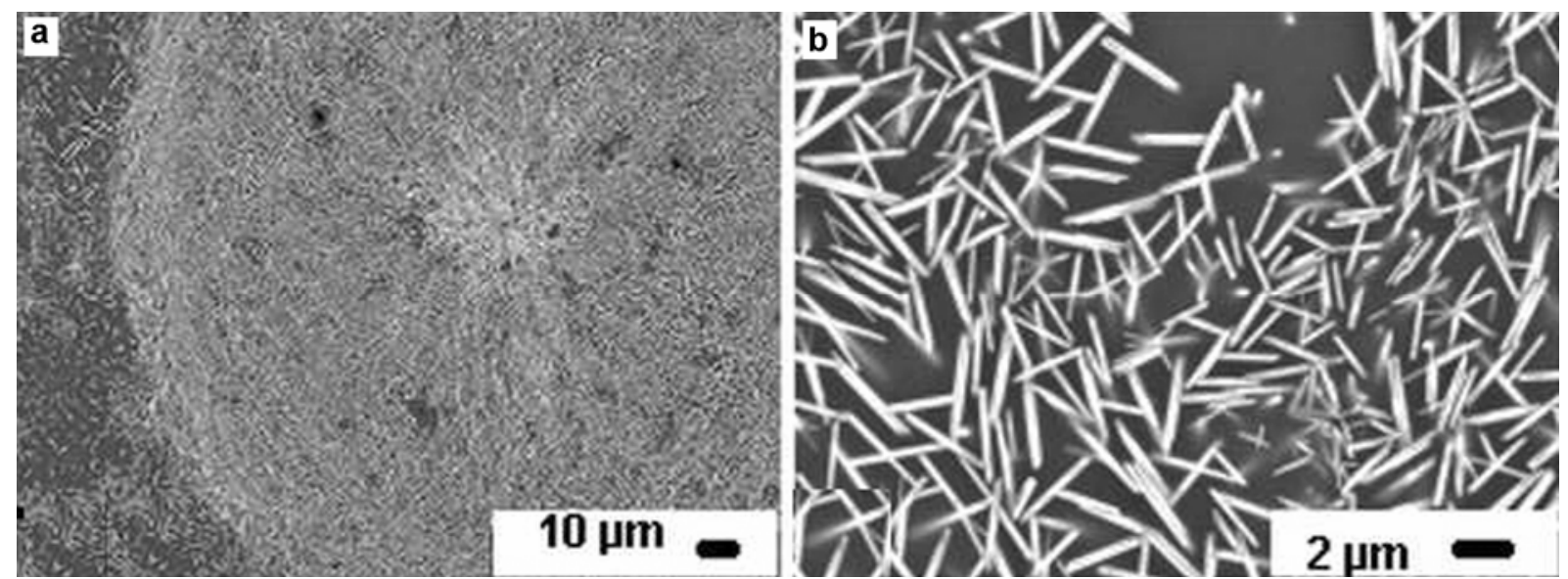

Figure 11. SEM micrographs of the CW3-based glaze exhibiting a. general and $\mathbf{b}$. detailed microstructural views.

zircon crystallization leading to the thought that its formation is favoured by shorter firing cycles.

The general microstructural views of the HZG-based glaze and the crystals formed are depicted in figures 3 and 4 . The acicular white crystals with different sizes belong to zircon and grey irregular-shaped ones to calcium aluminium silicate. The microstructure of the reference LZG-based glaze is indicated in figure 5. The 

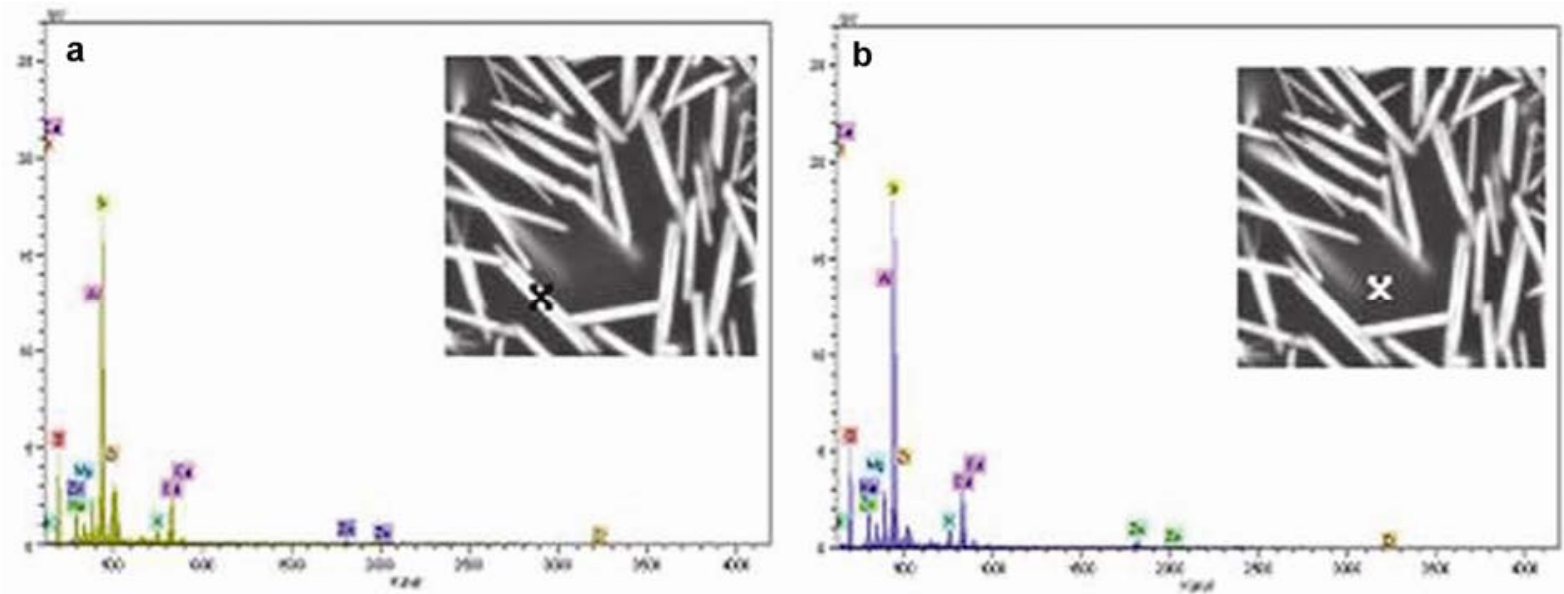

Figure 12. EDX patterns taken from the CW3-based glaze representing a. zircon occurrence and b. elemental constitutions of the glassy phase.
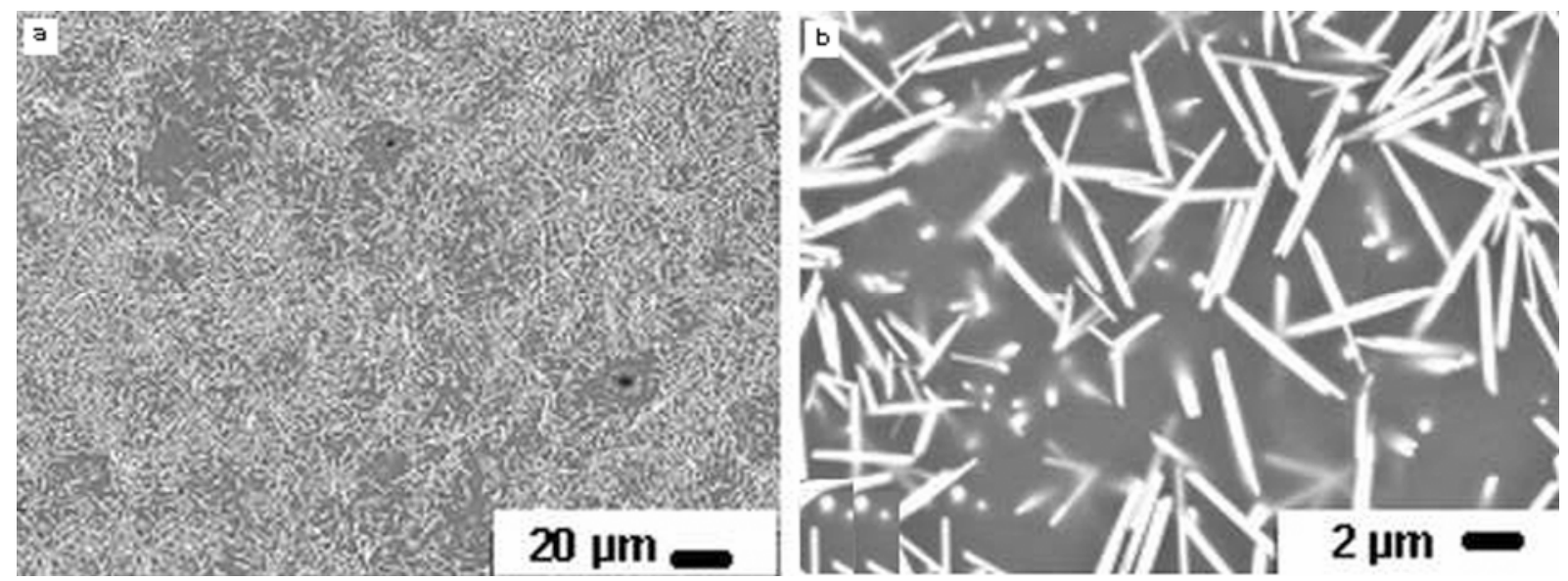

Figure 13. SEM micrographs of the CW4-based glaze showing a. general and $\mathbf{b}$. detailed microstructural views.
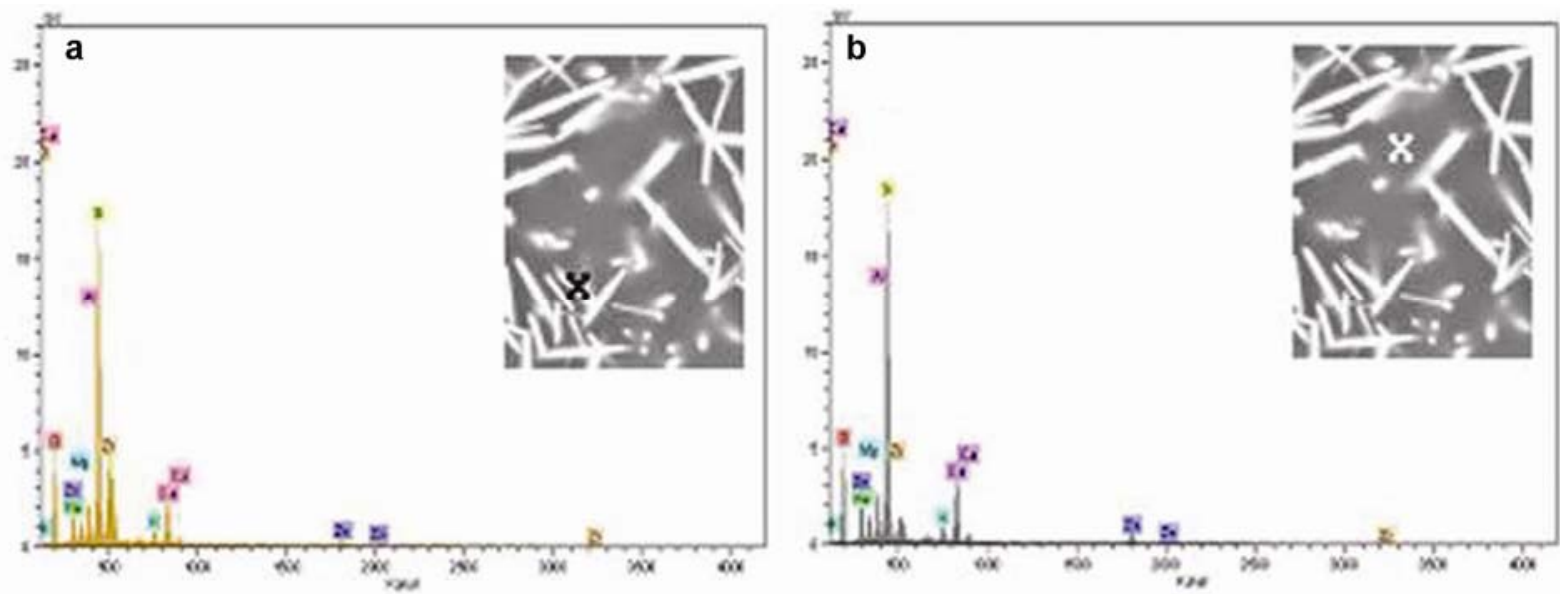

Figure 14. EDX patterns taken from the CW4 glaze inhibiting a. zircon occurrence and $\mathbf{b}$. elemental constitutions of the glassy phase.

acicular crystals originated from its frit belong to zircon (figure 6). These crystals are generally dispersed in the glassy matrix and they are approximately $2 \mu \mathrm{m}$ or smaller in size.
The general and detailed microstructural views of newly developed glazes are presented in figures 7, 9, 11 and 13. According to EDX studies, the acicular and round-shaped white crystals immersed in the glassy 


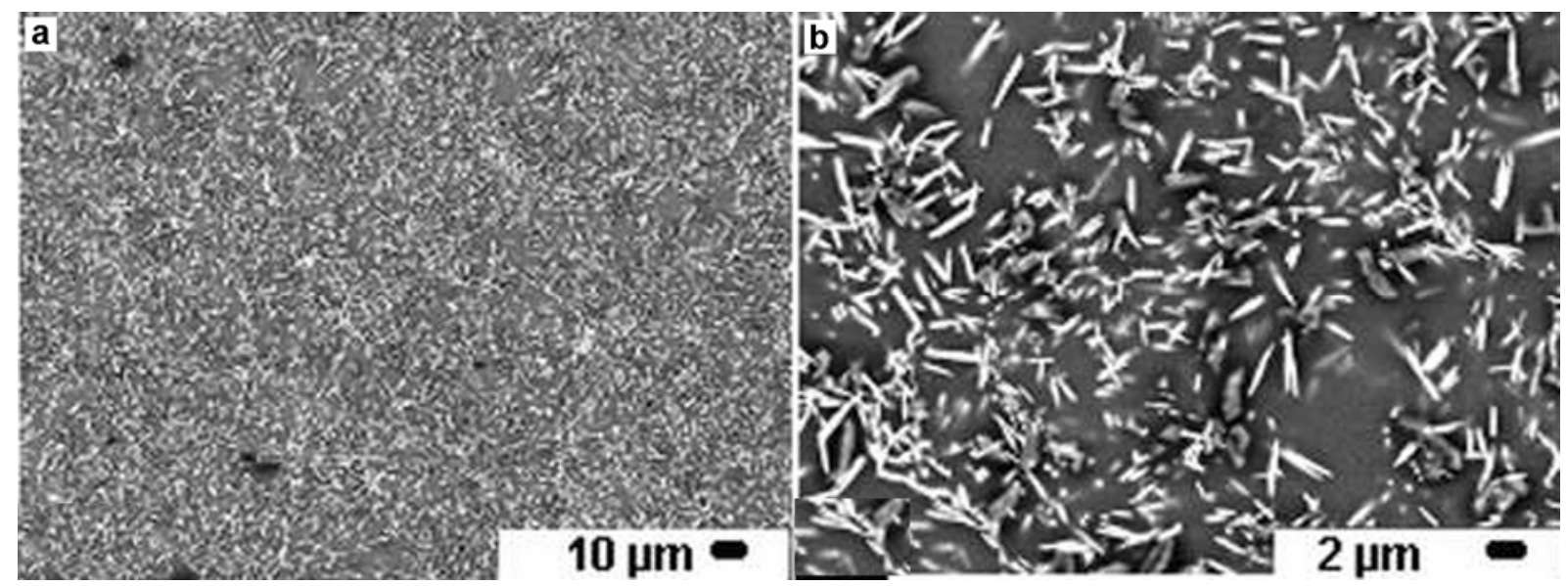

Figure 15. SEM micrographs of the industrially fired CW4-based glaze showing a. general and b. microstructural views.
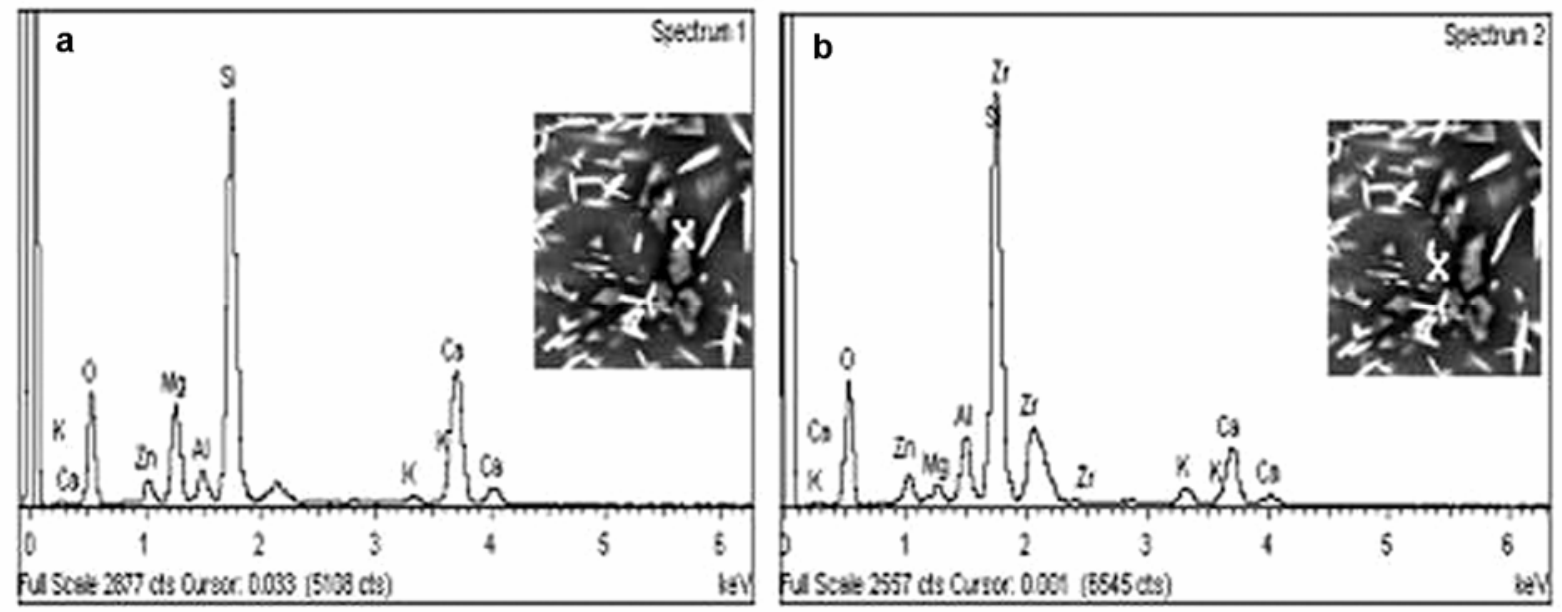

Figure 16. EDX patterns taken from the CW4-based glaze indicating a. petedunite and b. zircon occurrence.

matrix belong to zircon (figures 8, 10, 12, and 14). Generally, zircon crystals were found to be dispersed in a glassy matrix that exhibited immiscible-liquid-phase separation. In the studied glazes, crystal-free areas can also be observed, owing to zircon crystallization preferentially occurring from the surface of the original frit particles inwards (Levitskii et al 1998). The devitrification of zirconium silicate crystals gives rise to a homogenous microstructure in the $\mathrm{CW} \mathrm{1,2}$ and 4-based glazes. However, the CW 3-based one represents a heterogeneous microstructure with localized needle-shaped zircon crystals in the glassy matrix (figure 11). It is thought that this heterogeneous microstructure may explain the lower gloss value of the CW 3-based glaze when compared to the others. In such sense, the CW 4-based one (figures 13 and 14) has the highest gloss value (see table 5). Industrially fired CW-4 based glaze at $1140^{\circ} \mathrm{C}$ for 37 min has a homogenous microstructure. In the relatively short firing cycle, zircon and petedunnite crystals are identified (fig- ures 15 and 16). The amount of light reflected, and therefore, the opacity is dependent on both the number and the refraction index of the particles present in the glassy matrix (Karasu et al 2001). Zircon crystals were seen to have a tendency to become aligned through the surface of the glaze, and their elongation sizes may lead to a loss of opacity (Castilone et al 1999). SEM and EDX analyses revealed that the opacity of the LZG and CW 1-4-based glazes was achieved as a result of zircon crystallization and the concentrator waste usage in frit recipes is appropriate up to a certain level $(5 \%)$ for the $\mathrm{Na}_{2} \mathrm{O}-\mathrm{K}_{2} \mathrm{O}$ $\mathrm{MgO}-\mathrm{CaO}-\mathrm{SrO}-\mathrm{ZnO}-\mathrm{Al}_{2} \mathrm{O}_{3}-\mathrm{B}_{2} \mathrm{O}_{3}-\mathrm{ZrO}_{2}-\mathrm{SiO}_{2}$ glassceramic glaze system.

\section{Conclusions}

Differing amounts of borax concentrator waste (1.5-5\%) replaced certain level of acid boric in the frit recipes for $\mathrm{B}_{2} \mathrm{O}_{3}$ content and the final glaze surface properties were 
found to be similar to those of the industrially produced standard LZG-based glaze with lower zirconia (4.5$7 \cdot 5 \%)$ and $\mathrm{ZnO}(4 \cdot 5-7 \cdot 5 \%)$ contents. Zircon crystals originated from the frits during laboratory fast singlefiring of the glazed wall tiles at $1140^{\circ} \mathrm{C}$ for $55 \mathrm{~min}$. Industrial trials indicated that firing conditions influence the type of crystals in the glaze. Zircon and petedunnite were the main crystals of the glaze observed as a result of shorter firing time (37 min). Industrial application of the CW-4 based glaze confirmed that the glaze opacity, colour and gloss properties are stable under different firing conditions and cycles. Although the CW-4 frit batch which contains $1.5 \%$ concentrator waste gave better results in terms of glossiness and surface smoothness of the final fast single-fired opaque wall tile glazes, the others, in which the waste level was increased up to $5 \%$, could also be evaluated. It was determined that the borax wastes of Kirka region of Turkiye can be re-cycled in this type of glazes with the complete replacement of Na-feldspar in their frit batches without consequently causing any kind of glaze defects.

\section{Acknowledgements}

The authors would like to thank Industrial $\mathrm{PhD}$ Programme of State Planning Organization of Turkiye (Project No: 2004K1 20270) and TUBITAK (Science, Technology and Research Association of Turkiye) Programme of Industrial Research and Development Projects (TEYDEB) for support to the project (No. 3060236). Special thanks also go to the authorities and people of Kalefrit A. S. and Kaleseramik A. S. of Turkiye, for facilitating the study to be conducted satisfactorily.

\section{References}

Amoros J L, Escardino A, Orts M and Moreno A 1994 Br. Ceram. Trans. 93224

Castilone R J, Dattaguru S, Carty W and Snyder R L 1999 J. Am. Ceram. Soc. 822819

Chiang JF, Chen $\mathrm{P}$ and $\mathrm{Xu}$ Y 1994 US Patent No. 5369062

Djambazov S and Damgaliev D 2000 The Proceedings of the Congress Qualicer (Castellon, Spain: Official Chamber of Commerce, Industry and Navigation) 3 p. 55

Eppler R A and Eppler D R 2000 Glazes and glass coatings (Ohio: The American Ceramic Society) p. 62

Escardino A, Moreno A, Amoros J L, Gozalbo A, Aparici J and Sanchez L F 1996 Ceram. Acta 821

Escardino A, Moreno A, Amoros J L, Orts M J and Barba A 2000 Br. Ceram. Trans. 9972
Henkes E V, Onodo Y G and Carty M W 1996 Science of whitewares (Ohio: The American Ceramic Society) p. 358

Karasu B, Dolekcekic E and Ozdemir B 2001 Br. Ceram. Trans. 10081

Karasu B, Kaya G and Taykurt M 2006a The abstract book of the 9th international ceramic processing science symposium (Coral Springs, Florida) p. 24

Karasu B, Kaya G and Taykurt M 2006b The abstract book of the 9th international ceramic processing science symposium (Coral Springs, Florida), p. 25

Karasu B, Kaya G and Ozdemir O 2006c The proceedings of Sohn international symposium on advanced processing of metals and materials: principles, technologies and industrial practice (San Diego: TMS) p. 529

Karasu B, Kaya G, Taykurt M, Cakir A and Kavas T 2006d The proceeding book of the III international boron symposium (Ankara: Kozan Ofset Matbaac1lık), p. 91 (in Turkish)

Kaya G, Karasu B and Cakir A 2008 The proceedings of the X conference and exhibition of the European Ceramic Society, Silicates and traditional ceramics section (Baden-Baden: Göller Verlag GmbH) p. 1714

Kawamura T, Hayashi H and Inoko N 2005 United States Patent US 6881690 B2

Levitskii I A and Mazura N 2005 Glass Ceram. 627

Levitskii I A, Papko L F and Gailevich S A 1998 Glass Ceram. $\mathbf{5 5} 386$

Moreva A N and Levitskii I A 2006 Glass Ceram. 63122

Pekkan K K and Karasu B 2009a J. Mater. Sci. 442533

Pekkan K K and Karasu B 2009b J. Euro. Ceram. Soc. 29 1571

Pekkan K K, Karasu B and Onal H S 2007 The proceeding books of the IV ceramic, glass, enamel, glaze and pigment seminar with international participation (SERES 2007) (Eskisehir: Ongar Photocopy) p. 808 (in Turkish)

Pekkan K K, Karasu B and Onal H S 2008a The proceedings of the $X$ conference and exhibition of the European Ceramic Society, silicates and traditional ceramics section (BadenBaden: Göller Verlag GmbH) p. 1602

Pekkan K K, Karasu B and Onal H S 2008b The proceeding books of the qualicer 2008 Castellon, 2, P.BC p. 43

Pekkan K K, Karasu B and Onal H S 2008c The proceeding book of the II international boron workshop (Ankara) p. 325 (in Turkish)

Quinteiro E, Boschi A O, Leonelli C, Manfredini T and Siligardi C 2002 Proceedings of the Congress Qualicer (Castellon, Spain: Official Chamber of Commerce, Industry and Navigation) G1 p. 301

Sorli S, Tena M A, Mestre A, Llusar M and Monros G 2004 The Proceedings of the Congress Qualicer (Castellon, Spain: Official Chamber of Commerce, Industry and Navigation) P.G1-99

Taylor L 2001 Ind. Miner. 40996

Taylor J R and Bull A C 1986 Ceramics glaze technology (Oxford: Pergamon Press) p. 50

Yekta B E, Alizadeh P and Rezazadeh L 2006 J. Euro. Ceram. Soc. 263809 